\title{
Detection and Control of Fungal Outbreaks
}

\author{
Diego H. Caceres (D) Ratna Mohd Tap (D) Ana Alastruey-Izquierdo (D) \\ Ferry Hagen $(1)$
}

Received: 16 September 2020/ Accepted: 20 September 2020/Published online: 10 October 2020

(C) The Author(s) 2020

Keywords Emerging pathogen $\cdot$ Fungal infection · Immunodiagnostics · Molecular diagnostics $\cdot$ Molecular epidemiology ·

Nosocomial outbreak

The fungal kingdom contains an estimated 2.2-3.8 million species [1]. Fungi are ubiquitous and primarily co-exist with plants and animals, creating

Handling Editor: Vishnu Chaturvedi

D. H. Caceres $(\bowtie)$

Mycotic Diseases Branch, Centers for Disease Control and Prevention (CDC), 1600 Clifton Rd. NE, Atlanta, GA 30329, USA

e-mail: xju7@cdc.gov;

diegocaceres84@gmail.com

D. H. Caceres

Center of Expertise in Mycology Radboudumc/CWZ, Nijmegen, The Netherlands

\section{R. Mohd Tap}

Mycology Laboratory, Institute for Medical Research, National Institute of Health, Setia Alam,

40170 Shah Alam, Selangor, Malaysia

A. Alastruey-Izquierdo

Medical Mycology Reference Laboratory, National Center for Microbiology, Instituto de Salud Carlos III, Madrid, Spain mutual benefits, including the acquisition of vital nutrients and protection from pathogenic microorganisms. Generally, fungi are beneficial to humankind and are indispensable in the food production chain and in biotechnological processes like the production of chemical compounds and drugs. Approximately 600 species have been reported to cause human disease, mostly due to traumatic introduction into the host. An even smaller number cause serious superficial or invasive disease (https://www.clinicalfungi.org/). The dermatophytes cause superficial infections, but also deep infections, and negatively impact the quality of

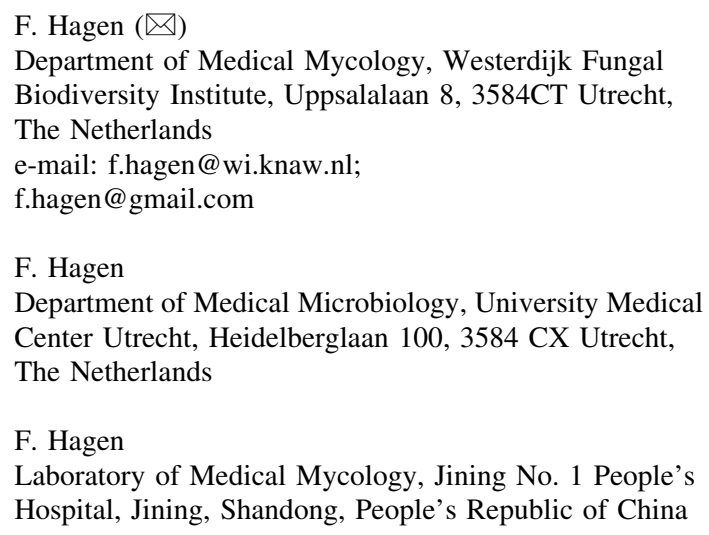


life of $\sim 1$ billion people worldwide [2-5]. Globally, Aspergillus, Candida, Cryptococcus, Pneumocystis, and Mucorales infections (the 'big five') are important causes of fungal morbidity and mortality, primarily affecting immunocompromised hosts [2, 6, 7]. Among these big five, Candida yeasts cause the largest number of infections, with annual estimates of 134 million mucosal infections, as well as 750,000 life-threatening bloodstream infections associated with mortality rates $>40 \%[2,8]$.

Outbreaks caused by fungi can be classified into two groups. The first consists of community-acquired outbreaks that are linked to outdoor activities, mostly seen in patients who perform a specific occupational or recreational activity and those who experienced a natural disaster or human conflicts [9-12]. The second group of fungal outbreaks is related to hospital care and has been increasingly reported during the past two decades, likely as a result of the increase in at-risk populations [13]. The sources of healthcare-associated outbreaks include construction near or renovation of healthcare facilities, contamination of water and ventilation systems, medicines and medical devices, and gaps in infection prevention measures [9-12, 14, 15]. An increasingly reported cause of fungal outbreaks is the emergence of novel resistant pathogens within hospital environments, clearly exemplified by the unprecedented emergence of Candida auris, as well as increasing incidence of previously rare resistant species like Candida krusei and Diutina rugosa [16-19].

This special issue covers several aspects of fungal outbreaks. The use of immunodiagnostic and molecular tests for the detection and control of community and healthcare-associated fungal outbreaks is presented [20] and specifically reviewed for Mucorales and the unculturable Pneumocystis jirovecii $[6,7]$. Fungal immunodiagnostic assays can detect either antigens, antibodies or metabolites, and are available in different methodologies, presenting from high laboratory complex complement fixation, to the point-of-care lateral flow assays. These assays are developed to detect specific or multiple pathogens. Caceres and colleagues reviewed the available immunodiagnostic assays and provided the ins and outs of these assays as well as an overview of the strengths and weaknesses of using each of them in a potential outbreak setting [20]. Linder and colleagues evaluated the performance of the 'pan-fungal' (1-3)- $\beta$ -
D-glucan (BDG) assay for the diagnosis of invasive pulmonary aspergillosis (IPA) using bronchoalveolar lavage (BAL) samples; they concluded that diagnostic accuracy of BDG using BAL was poor for the diagnosis of IPA [21]. Mucorales is an illustrious yet enigmatic cause of opportunistic infections and outbreaks. Despite their rapid progressive growth, they are difficult to diagnose as they cannot be detected by an immunodiagnostic assay, like the BDG assay, and thus culture (often negative), histopathology, imaging, and molecular diagnostics remain the diagnostic arsenal from which to choose. Walther and co-workers identified 32 outbreaks of mucormycosis, the majority ( $n=28)$ were hospital-acquired and four were community-acquired [7]. Interestingly, Walther and colleagues observed that only in few outbreaks molecular typing was applied to investigate clonality (see Table 1 in [7]). Hence, we can conclude that in the case of a suspected Mucorales outbreak there is much more to explore from a molecular epidemiological point of view. While sensitivity of culture in Mucorales is very low, Pneumocystis species are non-culturable fungi $[22,23]$; thus, molecular tools are essential to diagnose and study the epidemiology of this notorious culprit of nosocomial fungal outbreaks [6].

Two other fungal-like pathogens that are reviewed in this special issue are Prototheca [24] and Pythium [25], rarely identified by routine diagnostics but known to cause outbreaks. Prototheca are achlorophyllic algae that have a yeast-like colony morphology and therefore historically been studied by medical mycologists [24, 26]. Despite a recent outbreak among humans, protothecosis remain a relative rare cause of human disease, while it is widely known among veterinarians as a cause of bovine mastitis. Kano provided a summary on the history, biology, diagnostics, treatment, and current knowledge of Prototheca [24]. Like Prototheca, the aquatic oomycete Pythium insidiosum has been historically classified as a fungus, while it seems to be closer related to diatoms and algae $[25,26]$. In their review, Permpalung and colleagues provided an overview of the diagnosis and treatment of this quirky pathogen that causes infectionsranging from keratitis to life-threatening-in both humans and animals [25].

Infections with Talaromyces marneffei are geographically restricted to southeast Asia and are seen predominantly in people living with HIV [27]. Six decades ago, Penicillium marneffe $i$ was described as a 
novel pathogen, but since several years it is grouped as the sole pathogenic and dimorphic species within the genus Talaromyces [28, 29]. The history of $T$. marneffei was recently extensively reviewed [27], but it deserves attention in this special issue as Sethuraman and co-workers reported five apparent autochthonous cases among patients with different underlying disorders that lived outside the endemic region [30]. This highlights that the current map of endemic mycoses needs to be redrawn, not only for $T$. marneffei but also for Blastomyces, Coccidioides, Histoplasma, and Paracoccidioides as their incidence and geographic range has changed [31]. Ashraf and colleagues included an overview of reported cases due Emergomyces species, and they stated that the epidemiology is incomplete and that our understanding continues to evolve which is depicted by a recent reported case of E. pasteurianus from India [32].

Molecular typing is essential to understand emergence and spread of novel fungal pathogens. An overview of epidemiological typing tools, ranging from microsatellite typing, multi-locus sequencing typing to whole genome sequencing, for Candida glabrata provided alternatives to track and control the spread of this yeast [33]. A molecular diagnostic approach was used to study the natural reservoirs of Histoplasma capsulatum by investigating the presence of the pathogen in stored Argentinian wildlife tissue samples [34]. An in-depth literature study spanning seven decades of epidemiological data from Brazil identified characteristics of histoplasmosis of outbreaks on this country. Based on this characterization, authors suggested interventions to prevent exposure [35]. Rodrigues and co-workers reviewed the global epidemiology of Sporothrix species is in all aspects, and refined maps for the three major pathogenic species S. brasiliensis, S. schenckii, and S. globosa [36].

The detection and control of fungal outbreaks is complex and require coordination between the clinical microbiology laboratory, clinicians, epidemiologists, and public health microbiologists, including other professionals (environmental and veterinary staff) to ensure a 'One Health' approach. These professionals must form an investigative multidisciplinary team, together with decision-makers to ensure implementation of control measures [37]. The global lack of awareness of fungal diseases, limited laboratory capacity, and the absence of fungal diseases on the radar of most epidemiological and public health systems are major challenges [38]. The World Health Organization (WHO) and its regional offices, the Mycotic Disease Branch of the Centers for Disease Control and Prevention (CDC), the Global Action Fund for Fungal Infections (GAFFI), Leading International Fungal Education (LIFE), International Society for Human and Animal Mycology (ISHAM), Mycoses Study Group Education and Research Consortium (MSG-ERC), European Society for Clinical Microbiology \& Infectious Diseases-Fungal Infections Study Group (ESCMID/EFISG), and the European Confederation of Medical Mycology (ECMM) have launched a variety of initiatives, focused principally in education and advocacy of fungal diseases. These initiatives range from the Fungal Disease Awareness Week (September 21-25, 2020) to e-courses, specialized working groups, and guideline development [39-44]. Given the increasing global emergence of novel multidrug-resistant outbreakcausing fungal pathogens, coordinated international interdisciplinary collaboration to manage them is needed more than ever.

Acknowledgements We want to thank Brendan R. Jackson and Shawn R. Lockhart, Mycotic Diseases Branch, Centers for Disease Control and Prevention, for document review. Diego H. Caceres acknowledges Oak Ridge Institute for Science and Education (ORISE). The findings and the conclusions in this report are those of the authors and do not necessarily represent the official position of the Centers for Disease Control and Prevention.

Open Access This article is licensed under a Creative Commons Attribution 4.0 International License, which permits use, sharing, adaptation, distribution and reproduction in any medium or format, as long as you give appropriate credit to the original author(s) and the source, provide a link to the Creative Commons licence, and indicate if changes were made. The images or other third party material in this article are included in the article's Creative Commons licence, unless indicated otherwise in a credit line to the material. If material is not included in the article's Creative Commons licence and your intended use is not permitted by statutory regulation or exceeds the permitted use, you will need to obtain permission directly from the copyright holder. To view a copy of this licence, visit http://creativecommons.org/licenses/by/4.0/. 


\section{References}

1. Hawksworth DL, Lücking R. Fungal diversity revisited: 2.2 to 3.8 million species. Microbiol Spectr. 2017. https://doi. org/10.1128/microbiolspec.FUNK-0052-2016.

2. Bongomin F, Gago S, Oladele RO, Denning DW. Global and multi-national prevalence of fungal diseases-estimate precision. J Fungi (Basel). 2017;3(4):57. https://doi.org/10. 3390/jof3040057.

3. Bouchara JP, Mignon B, Chaturvedi V. Dermatophytes and dermatophytoses: a thematic overview of state of the art, and the directions for future research and developments. Mycopathologia. 2017;182(1-2):1-4. https://doi.org/10. 1007/s11046-017-0114-z.

4. Guanziroli E, Pavia G, Guttadauro A, Sangalli R, Mancini LL, Costanzo A. Deep dermatophytosis caused by Trichophyton verrucosum in an immunosuppressed patient: successful outcome with terbinafine. Mycopathologia. 2019;184(4):543-5. https://doi.org/10.1007/s11046-01900357-4.

5. Huang C, Peng Y, Zhang Y, Li R, Wan Z, Wang X. Deep dermatophytosis caused by Trichophyton rubrum. Lancet Infect Dis. 2019;19(12):1380. https://doi.org/10.1016/ S1473-3099(19)30551-1.

6. Dellière S, Gits-Muselli M, Bretagne S, Alanio A. Outbreak-causing fungi: Pneumocystis jirovecii. Mycopathologia. 2019. https://doi.org/10.1007/s11046-01900408-w.

7. Walther G, Wagner L, Kurzai O. Outbreaks of Mucorales and the species involved. Mycopathologia. 2019. https:// doi.org/10.1007/s11046-019-00403-1.

8. Bassetti M, Giacobbe DR, Vena A, Trucchi C, Ansaldi F, Antonelli $\mathrm{M}$, et al. Incidence and outcome of invasive candidiasis in intensive care units (ICUs) in Europe: results of the EUCANDICU project. Crit Care. 2019;23(1):219. https://doi.org/10.1186/s13054-019-2497-3.

9. Benedict K, Richardson M, Vallabhaneni S, Jackson BR, Chiller T. Emerging issues, challenges, and changing epidemiology of fungal disease outbreaks. Lancet Infect Dis. 2017;12:e403-e411411. https://doi.org/10.1016/S14733099(17)30443-7.

10. Benedict K, Mody RK. Epidemiology of histoplasmosis outbreaks, United States, 1938-2013. Emerg Infect Dis. 2016;22(3):370-8. https://doi.org/10.3201/eid2203. 151117.

11. Benedict K, Roy M, Chiller T, Davis JP. Epidemiologic and ecologic features of blastomycosis: a review. Curr Fungal Infect Rep. 2012;6(4):327-35. https://doi.org/10.1007/ s12281-012-0110-1.

12. Freedman M, Jackson BR, McCotter O, Benedict K. Coccidioidomycosis outbreaks, United States and worldwide, 1940-2015. Emerg Infect Dis. 2018;24(3):417-23. https:// doi.org/10.3201/eid2403.170623.

13. Caceres DH, Chiller T. Epidemiología global de las micosis. In: API, editor. Manual de Infecciones Fúngicas Sistémicas 2019.

14. Bougnoux ME, Brun S, Zahar JR. Healthcare-associated fungal outbreaks: new and uncommon species, new molecular tools for investigation and prevention.
Antimicrob Resist Infect Control. 2018;7:45. https://doi. org/10.1186/s13756-018-0338-9.

15. Kanamori H, Rutala WA, Sickbert-Bennett EE, Weber DJ. Review of fungal outbreaks and infection prevention in healthcare settings during construction and renovation. Clin Infect Dis. 2015;61(3):433-44. https://doi.org/10.1093/cid/ civ297.

16. Caceres DH, Forsberg K, Welsh RM, Sexton DJ, Lockhart SR, Jackson BR, et al. Candida auris: a review of recommendations for detection and control in healthcare settings. J Fungi (Basel). 2019;5(4):111. https://doi.org/10.3390/ jof5040111.

17. Caceres DH, Rivera SM, Armstrong PA, Escandon P, Chow $\mathrm{N}$, Ollave MV, et al. Case-case comparison of Candida auris vs. other Candida species bloodstream infections: results of an outbreak investigation in Colombia. Mycopathologia. 2020. https://doi.org/10.1007/s11046-02000478-1.

18. Colombo AL, Júnior JNA, Guinea J. Emerging multidrugresistant Candida species. Curr Opin Infect Dis. 2017;30(6):528-38. https://doi.org/10.1097/QCO. 0000000000000411.

19. de Jong AW, Hagen F. Attack, defend and persist: how the fungal pathogen Candida auris was able to emerge globally in healthcare environments. Mycopathologia. 2019;184(3):353-65. https://doi.org/10.1007/s11046-01900351-w.

20. Caceres DH, Chiller T, Lindsley MD. Immunodiagnostic assays for the investigation of fungal outbreaks. Mycopathologia. 2020. https://doi.org/10.1007/s11046-02000452-x.

21. Linder KA, Kauffman CA, Zhou S, Richards BJ, Kleiboeker $\mathrm{S}$, Miceli MH. Performance of the $(1,3)$-beta-D-glucan assay on bronchoalveolar lavage fluid for the diagnosis of invasive pulmonary aspergillosis. Mycopathologia. 2020. https://doi.org/10.1007/s11046-020-00479-0.

22. Liu Y, Fahle GA, Kovacs JA. Inability to culture Pneumocystis jirovecii. mBio. 2018;9(3):e00939-e1018. https://doi. org/10.1128/mBio.00939-18.

23. Schildgen V, Mai S, Khalfaoui S, Lüsebrink J, Pieper M, Tillmann RL, et al. Pneumocystis jirovecii can be productively cultured in differentiated CuFi-8 airway cells. mBio. 2014;5(3):e01186-e1214. https://doi.org/10.1128/mBio. 01186-14.

24. Kano R. Emergence of fungal-like organisms: Prototheca. Mycopathologia. 2019. https://doi.org/10.1007/s11046019-00365-4.

25. Permpalung N, Worasilchai N, Chindamporn A. Human pythiosis: emergence of fungal-like organism. Mycopathologia. 2019. https://doi.org/10.1007/s11046-01900412-0.

26. Adl SM, Simpson AG, Lane CE, Lukeš J, Bass D, Bowser SS, et al. The revised classification of Eukaryotes. J Eukaryot Microbiol. 2012;59(5):429-93. https://doi.org/ 10.1111/j.1550-7408.2012.00644.x.

27. Cao C, Xi L, Chaturvedi V. Talaromycosis (Penicilliosis) due to Talaromyces (Penicillium) marneffei: Insights into the clinical trends of a major fungal disease 60 years after the discovery of the pathogen. Mycopathologia. 2019;184(6):709-20. https://doi.org/10.1007/s11046-01900410-2. 
28. Yilmaz N, Visagie CM, Houbraken J, Frisvad JC, Samson RA. Polyphasic taxonomy of the genus Talaromyces. Stud Mycol. 2014;78:175-341. https://doi.org/10.1016/j.simyco. 2014.08.001.

29. Segretain G. Penicillium marneffei n.sp., agent of a mycosis of the reticuloendothelial system. Mycopathol Mycol Appl. 1959;11:327-53. https://doi.org/10.1007/BF02089507.

30. Sethuraman N, Thirunarayan MA, Gopalakrishnan R, Rudramurthy S, Ramasubramanian V, Parameswaran A. Talaromyces marneffei outside endemic areas in India: an emerging infection with atypical clinical presentations and review of published reports from India. Mycopathologia. 2020. https://doi.org/10.1007/s11046-019-00420-0.

31. Ashraf N, Kubat RC, Poplin V, Adenis AA, Denning DW, Wright L, et al. Re-drawing the maps for endemic mycoses. Mycopathologia. 2020. https://doi.org/10.1007/s11046020-00431-2.

32. Capoor MR, Mishra N, Kolte S, Singla G, Gogna A, Rudramurthy S, et al. Disseminated Emergomyces pasteurianus infection in India: a case report and a review. Mycopathologia. 2020;185(1):193-200. https://doi.org/10. 1007/s11046-019-00387-y.

33. Gabaldón T, Gómez-Molero E, Bader O. Molecular typing of Candida glabrata. Mycopathologia. 2019. https://doi. org/10.1007/s11046-019-00388-x.

34. Canteros CE, Toranzo AI, Levis S, Salas HD, López-Joffre MC, Suárez-Alvarez RO. Use of an Argentinean wildlife tissue collection for epidemiological studies of histoplasmosis. Mycopathologia. 2020. https://doi.org/10.1007/ s11046-020-00430-3.

35. Guerra BT, Almeida-Silva F, Almeida-Paes R, Basso RP, Bernardes J, Almeida MA, et al. Histoplasmosis outbreaks in Brazil: lessons to learn about preventing exposure. Mycopathologia. 2019. https://doi.org/10.1007/s11046019-00389-w.

36. Rodrigues AM, Della Terra PP, Gremião ID, Pereira SA, Orofino-Costa R, de Camargo ZP. The threat of emerging and re-emerging pathogenic Sporothrix species. Mycopathologia. 2020. https://doi.org/10.1007/s11046-02000425-0.

37. CDC. Principles of Epidemiology in Public Health Practice 2012. https://www.cdc.gov/csels/dsepd/ss1978/SS1978. pdf.
38. Denning DW. The ambitious ' $95-95$ by 2025 ' roadmap for the diagnosis and management of fungal diseases. Thorax. 2015;70(7):613-4. https://doi.org/10.1136/thoraxjnl-2015207305.

39. Chakrabarti A, Meis JF, Cornely OA. International Society for Human and Animal Mycology (ISHAM)-new initiatives. J Fungi (Basel). 2020;6(3):E97. https://doi.org/10. 3390/jof6030097.

40. Cornely OA, Alastruey-Izquierdo A, Arenz D, Chen SCA, Dannaoui E, Hochhegger B, et al. Global guideline for the diagnosis and management of mucormycosis: an initiative of the European Confederation of Medical Mycology in cooperation with the Mycoses Study Group Education and Research Consortium. Lancet Infect Dis. 2019;19(12):e405-e421421. https://doi.org/10.1016/ S1473-3099(19)30312-3.

41. Cornely OA, Lass-Flörl C, Lagrou K, Arsic-Arsenijevic V, Hoenigl M. Improving outcome of fungal diseases-guiding experts and patients towards excellence. Mycoses. 2017;60(7):420-5. https://doi.org/10.1111/myc.12628.

42. Hoenigl M, Gangneux JP, Segal E, Alanio A, Chakrabarti A, Chen SC, et al. Global guidelines and initiatives from the European Confederation of Medical Mycology to improve patient care and research worldwide: new leadership is about working together. Mycoses. 2018;61(11):885-94. https://doi.org/10.1111/myc.12836.

43. Oladele RO, Akase IE, Fahal AH, Govender NP, Hoenigl $\mathrm{M}$, Gangneux JP, et al. Bridging the knowledge gap on mycoses in Africa: setting up a Pan-African Mycology Working Group. Mycoses. 2020;63(3):244-9. https://doi. org/10.1111/myc.13044.

44. Pan American Health Organization (PAHO) and World Health Organization (WHO). Diagnosing and managing disseminated histoplasmosis among people living with HIV. Washington, D.C. 2020. License: CC BY-NC-SA 3.0 IGO.

Publisher's Note Springer Nature remains neutral with regard to jurisdictional claims in published maps and institutional affiliations. 